Copyright (C) 2021 by Cherkas Global University

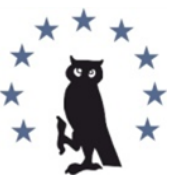

Published in the USA

Russkii Arkhiv

Has been issued since 1863 .

E-ISSN: 2413-726X

2021. 9(2): 165-180

DOI: 10.13187/ra.2021.2.165

https://ra.cherkasgu.press

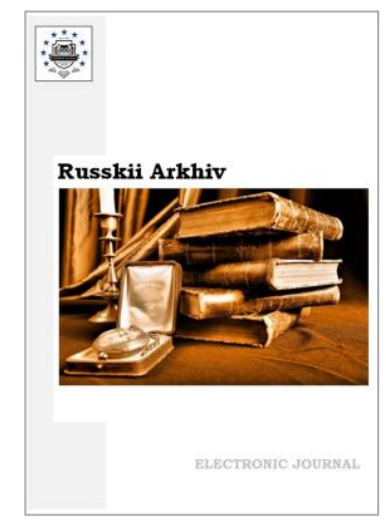

\title{
Maikop Oil Fields during the Great October Revolution and the Civil War of 1918- 1922 (according to the Memoirs of Potap Denisovich Provorotov)
}

Preparation for publication, introductory article and comments

Igor O. Tumentseva, *

a Volgograd Institute of Management of the Russian Presidential Academy of National Economy and Public Administration, Russian Federation

\section{Abstract}

This publication introduces into scientific circulation, for the first time, the memoirs of one of the oldest workers of the Maikop oil fields, Secretary of the Union of Miners, Potap Denisovich Provotorov, dedicated to the beginning of oil development in the Maikop Department of the Kuban Cossack army, about the events of the Russian Revolution and the Civil War of 1917-1922, as well as the beginning of socialist construction. Although the author belonged to the generation of revolutionaries and at the time of the described events was a member of the RKP(b), for unknown reasons, in the $30-50$ s of the $20^{\text {th }}$ century, he fell out of the local nomenclature and ended his career as a simple worker. He wrote his memories for the anniversary collection "The Generation of the October", in which they, apparently for political reasons, were not included. Although this is the only known memories of the revolutionary events on "Maineft".

Keywords: beginning of oil development in the North Caucasus, The Maikop fields and revolution, Reds, Whites, Greens, Establishment of Soviet Power.

История Майкопских нефтяных промыслов с момента их создания и по настоящее время неизменно вызывает большой интерес как у специалистов геофизиков и нефтяников, так и у историков. Это связано с тем, что уникальность залегания нефтеносных пластов, которую исследовали инженеры Владимир Иванович Винда (Винда, 1910; Винда, 1910-1912; Винда, 1911a; Винда, 1911b; Винда, 1916) и Евгений Максимович Юшкин (Юшкин, 1910), надолго превратили Майкопские нефтяные промыслы в полигон для апробации новейших технологий добычи нефти (Иголкин, 2000).

Изучая историю Майкопских нефтяных промыслов, исследователи используют главным образом научные статьи геологов-нефтяников и архивные документы (ГАКК. Ф. Р-948. Оп. 1. Д. 134). Воспоминания инженеров и рабочих Майкопских нефтяных промыслов для большинства историков остаются неизвестными и не используются (Пономарев, Штейнер, 1958; Дубовицкий, 1966; Косторниченко, 2001; Сильванюк, 2011; Сильванюк, 2012).

В 1967 г. в ознаменование пятидесятилетнего юбилея Великой Октябрьской социалистической революции ветераны города Хадыженска, где в то время располагался

\footnotetext{
${ }^{*}$ Corresponding author

E-mail addresses: tijumencev@mail.ru (I.O. Tumentsev)
} 
центр Майкопских нефтяных промыслов - Нефтегазодобывающее управление (далее НГДУ) «Хадыженнефть» - задумали издать сборник воспоминаний «Поколение Октября», в котором предполагалось поместить мемуары участников Гражданской войны, первых работников НГДУ «Хадыженнефть», зачинателей коллективизации, культурной революции и партизанского движения в Хадыженске в годы Великой Отечественной войны. Несмотря на большую подвижническую работу авторского коллектива и редакционной коллегии, осуществить проект в то время не удалось. Материалы к сборнику хранились в Хадыженской средней школе № 15, которую в 1975 г. закончил автор этих строк. В результате критического анализа нам удалось не только восстановить текст сборника, но и проследить основные этапы редакторской работы. Сборник вышел в свет в 2017 г. к столетию революции (Поколение Октября, 2017).

Анализируя материалы сборника «Поколение Октября», мы обратили внимание на воспоминания Потапа Денисовича Провоторова «Краткое воспоминание о Майкопских нефтяных промыслах Краснодарского края», которые по неизвестным нам причинам в сборник не вошли еще на раннем этапе работы над изданием.

Потап Денисович Провоторов родился 23 декабря 1883 г., работал на Майкопских нефтяных промыслах с 1910 г. Был свидетелем первых буровых работ и последующей «нефтяной горячки». В Первой мировой войне участия не принимал, так как воспользовался бронью, которую предоставляли рабочим-нефтяникам. После Октябрьской революции вошел в Союз горняков. Весной 1918 г. был избран членом Совета рабочих, солдатских и крестьянских депутатов «Майнефти». Собирался уйти из станицы Апшеронской (сейчас - город Апшеронск) вместе с Таманской армией, но был оставлен на промыслах «Майнефти» для подпольной работы. В 1920-х гг. был избран секретарем Союза горняков и продолжал работу на промыслах. Во второй половине 1930х гг. все руководство треста «Майнефть» подверглось репрессиям, а сам поселок, только что ставший городом (Здравствуй новый социалистический город, 1935), был опять преобразован в поселок. Примечательно, что с этого момента воспоминания П.Д. Провоторова становятся отрывочными и лапидарными, но в списках репрессированных он не упоминается. В годы Великой Отечественной войны П.Д. Провоторов, по-видимому, был в эвакуации, так как среди партизан и подпольщиков его имени нет (Готьван, 2012). После войны работал на нефтяных промыслах до 1966 г., после чего вышел на пенсию.

Значительный интерес в сочинении П.Д. Провоторова представляют воспоминания о взаимоотношениях иностранных специалистов и русских рабочих. Имена иностранцев сильно искажены, поэтому в примечаниях помещены варианты из сочинений главного геолога НГДУ «Хадыженнефть» Н.П. Соколова (Соколов, 2017; Соколов, 1970) и воспоминаний первого директора Апшеронского краеведческого музея и его сына краеведа Ильи Гавриловича и Владимира Ильича Уваровых (Заборовская, Тюменцев, Ухина, 2014; Уваров, 2010)ํ.

Уникальны описания событий Гражданской войны на промыслах «Майнефти», их национализации, социалистических преобразованиях в Нефтегорске. Причем все описываемые события автор точно датирует. В воспоминаниях много фамилий, от руководителей «Майнефти» до простых рабочих, правда имен и отчеств практически нет, поэтому там, где нам их удавалось восстановить, мы заключали инициалы или имена в квадратные скобки.

Текст воспоминаний П.Д. Провоторова напечатан на 11 листах формата А 4 на механической печатной машинке через половину интервала. Листы 1-7, по всей видимости, относятся ко второму экземпляру машинописной закладки, а 8-11 к третьей. Машинописная пагинация в верхнем правом углу. Редакторская правка отсутствует. В конце приводится дата написания воспоминаний и некоторые сведения об авторе. Рукопись хранится в музее Муниципального общеобразовательного учреждения школа № 15 города Хадыженска.

\footnotetext{
${ }^{1}$ Мы благодарны автору за предоставленную возможность скопировать эту рукопись из его личного архива для нашей работы.
} 


\section{Потап Денисович Провоторов \\ Краткое воспоминание о Майкопских нефтяных промыслах Краснодарского края}

Майкопские нефтяные промыслы расположены в юртах станиц Апшеронской, Ширванской ${ }^{1}$, Нефтяной $^{2}$, Хадыженской ${ }^{3}$ и Кабардинской 4 . Эти станицы были населены еще в 1860, 1861, 1863, 1862 годах ${ }^{5}$ [на территории] Майкопского отдела ${ }^{6}$ [Кубанского казачьего войска].

Еще до населения этих станиц уже были выходы нефти на поверхность земли. Местные жители копали неглубокие колодцы под названием колодцы Нефтянские и Ширванские 7 , собирали нефть ведрами, наливали в соченки ${ }^{8}$ и вывозили продавать в Майкоп и дальше, обменивали на хлеб и другие продукты питания. Как видно, Кубанское казачество (войсковое управление) мало было заинтересовано [в том, чтобы] приступить к разработке столь ценного продукта - нефти 9 .

В начале XX в. Кубанское войсковое управление разрешило приступить к разработке нефти в указанных станицах. Инженеры, техники, геологи приступили к нарезке участков, признанных нефтеносными площадями, всем желающим приобрести нефтяные участки для бурения. В этой работе деятельное участие принимал областной инженер Владимир Иванович Винда. Кубанское войсковое управление продавало эти участки по стоимости... ${ }^{10}$ Кроме того, платили налоги с десятины по 25 руб. ежегодно. Для наблюдения за работой по бурению и эксплуатации Кубанское войсковое управление назначило своих доверенных чиновников контролеров.

С 1907 г. стали готовиться к бурению скважин на III-м отводе - хозяин участка купец [В.М.] Селитренников, на участке № 16 - хозяин участка князь [И.Н. Львов]-Салтыков ${ }^{11}$ (управляющий Чингири). Из Баку приехали с инструментом подрядчик Арестов и буровой мастер Смагин и другие рабочие. Бурение производилось вручную, частично паровой машиной. Особого оборудования не завозилось. Построек для жилья и производственных [помещений] строилось мало. Для рабочих сооружались ${ }^{12}$ казармы, [где спали] на нарах, некоторые жили в землянках или шалашах, нанимали частные квартиры в станицах Ширванской, Апшеронской, Нефтяной. Местные жители работали на промыслах по обслуживанию транспортом на своих быках, лошадях по перевозке всевозможных грузов. На площади, признанной нефтеносной, рос непроходимый первобытный лес, в котором было много зверей: медведей, кабанов, коз и др. ${ }^{13}$

1 Ширванская станица основана в 1863 г. Ныне административный центр сельского поселения Апшеронского района Краснодарского края.

2 Нефтяная станица основана в 1863 г. Ныне входит в состав Нефтегорского поселения Апшеронского района Краснодарского края (Ивин, 2016).

3 Хадыженская станица основана в 1864 г. Ныне город Хадыженск - центр городского поселения в Апшеронском районе Краснодарского края (Сирота, 2017).

4 Кабардинская станица основана в 1864 г. Ныне центр сельского поселения Апшеронского района Краснодарского края (Никитенков, 2017).

5 В действительности, в 1863-1864 гг.

6 Майкопский отдел как административная единица был создан только в 1883 г. В 1863-1864 гг. это была территория размещения станиц 26-го и 27-го конных полков Кубанского казачьего войска.

7 Один из таких колодцев автор видел в Родионовой балке - правом притоке реки Хадажки на окраине г. Хадыженска.

8 Соченки - разновидность тары для перевозки нефти. Название, видимо, происходит от глагола «сочать».

9 Ходульное для того времени обличение «проклятого капиталистического прошлого» в противовес «нынешнему процветанию». Сейчас наоборот можно встретить обличения «тоталитарного советского режима» в противовес дореволюционному и нынешнему «процветанию».

10 Автор оставил место, для того чтобы вписать стоимость участка, но так и не заполнил пробел.

11 Вероятно, автор имеет ввиду светлейшего князя И.Н. Салтыкова (1870-1941) - генерала, члена Государственного совета, Санкт-петербургского губернского предводителя дворянства.

12 В тексте повтор: «строились».

13 В тексте повторно: «зверей». 
Большая заслуга по изысканию и разведке нефтяных площадей принадлежит покойному геологу академику Губкину Ивану Михайловичу (Губкин, 1937), он здесь работал в 1911 г., в 1912 и 1913 гг. Он наметил вехи далеко за пределами Хадыжейํ․

В 1909 г., в июне месяце на третьем отводе внезапно на ${ }^{2}$ буровой № 2 [B.M.] Селитринникова ударил фонтан легкой нефти большой силы с глубины 135 метров. Закрыть его не было возможности из-за отсутствия необходимого технического оборудования. Стали копать земляные амбары, насыпать плотины через речушку Чекохз. Из-за отсутствия надзора по технике безопасности некоторые рабочие не имели представления, что такое нефть, холодно относились к делу4. Невдалеке от фонтана закурили папиросы, все воспламенилось, пошла огненная лава по речушке Чекох, по реке Пшеха 5 [от] ст[аницы] Ширванской в реку Белая, из реки Белой в реку Кубань и Азовское море, много погибло рыбы. Были слухи, что Кубанское войсковое управление крепко оштрафовало нефтепромышленника [В. М.] Селитринникова за этот фонтан.

Этот фонтан наделал много шума на весь мир. Иностранные нефтяные короли быстро стали слетаться в Екатеринодар, ст[аницу] Апшеронскую - англичане, немцы, шведы, французы, поляки и другие нефтепромышленники для покупки участков на Майкопских нефтяных промыслах. Началась горячая продажа, вернее, спекуляция. Многие ловкие люди подработали хорошо. Большинство участков приобрели англичане. Главные аукционеры: Твице Джеффрис 6 , Дабель 7 Федерсон ${ }^{8}$, Нарко Пени ${ }^{9}$ Вольтон Вискин, Баеро, Литль, Монтгомери ${ }^{10}$ и др. ${ }^{11}$ Многие промышленники приступили к строительству жилья и производственных помещений, строились квартиры для управляющих, инженеров, техников, буровых мастеров, машинистов, конторы и казармы для рабочих.

В 1910 г. в ст[анице] Апшеронской был организован совет нефтепромышленников. Для порядка на промыслах был приглашен военный пристав со штатом стражников. На участке № 216 построена больница на 15 коек, штат больницы 1 врач, 2 фельдшера, 1 акушерка. Дорога от ст[аницы] Апшеронской до промыслов проходила через Хопры ${ }^{12}$, расстояние 15 км. Ст[аница] Апшеронская стала жить шумно. В Апшеронской были почта и телеграф. Все рабочие и служащие, приезжающие на промыслы ${ }^{13}$, останавливались в Апшеронской для подыскания работы. Состав рабочих и служащих на промыслах: русские, лезгины, осетины, грузины, татары и др. Зарплата рабочих в один день - 80 к. и 1 руб., рабочий день - 10,5 часов.

Фирма «Шпис», немецкий участок 533, рабочий день был 8-ми часовой. Всего рабочих и служащих приблизительно было в то время более двух тысяч человек.

\footnotetext{
${ }^{1}$ В современной историографии справедливо отмечено, что роль И.М. Губкина в изучении нефтяных разработок «Майнефти» и других месторождений сильно преувеличена. Утверждается, что он стоит в одном ряду с канонизированными при жизни в «классики» сталинскими академиками Т.Д. Лысенко и Н.Я. Марром, повинен в репрессиях и пр. Действительно, в советской литературе роль В.И. Винда, Е.М. Юшкина и других предшественников И.М. Губкина практически не учитывалась, и все научные достижения приписывались академику. Однако, нельзя не видеть, что после проведенных И.М. Губкиным и его сотрудниками исследований «Майнефть», во второй половине 1920-х гг. находившаяся на грани закрытия, к началу Великой Отечественной войны вышла на второе место в стране по объемам добычи нефти, обогнав «Грознефть», к которой ранее была присоединена из-за нерентабельности. Вопрос требует дополнительных исследований и более взвешенных и объективных оценок (Галкин, 2003: 469-471).

2 В тексте: «в».

3 Ныне эта река Нефтяная

4 В тексте: «этому».

5 Пшеха - река в Краснодарском крае и Республике Адыгее, левый приток Белой. Длина реки 139 км

6 У П.Д. Провоторова ошибочно «Дефрес». У В.И. Уварова, использовавшего в своем сочинении о Нефтегорске текст П.Д. Провоторова, также ошибочно: «Джефрис» (Уваров, 2010: 10).

7 У В.И. Уварова: «Догбель» (Уваров, 2010: 10).

8 Там же (Уваров, 2010: 10).

9 У В.И. Уварова: «Пине» (Уваров, 2010: 10).

10 В тексте ошибочно: «Мангомери». У В.И. Уварова: «Мантгомери». (Уваров, 2010: 10).

11 В сочинении И.Г. Уварова упоминаются также: Мак-Гарвий, Шпис, Горберт, Кларк Гувер, Педерсон (Уваров, 2010: 10; Заборовская и др., 2014: 193).

12 Ныне северо-восточный микрорайон Нефтегорска.

13 Здесь и далее в авторском тексте: «промысла».
} 
Нефтепромышленники [В.М.] Селитринников и князь [И.Н. Львов]-Салтыков свои участки продали англичанам. Англичане широко развернули работу по бурению и эксплуатации нефти. Строительство технических сооружений построены: Нефтекачка 8 до Краснодара, Нефтекачка 6 до Туапсе, Нефтекачка 6 в ст[анице] Ширванской․․

Работа кипела день и ночь. Работало несколько бурильных станков галицинских, ударного бурения, без подрядчиков ${ }^{2}$. Построен Керосиновый завод в ст[анице] Ширванской. Склад товаров, вырабатываемых заводом, находился на девятом километре шоссе ст[аницы] Апшеронской [до] г[орода] Майкопа. Завод был перевезен в Краснодар в 1915 г.

Другие нефтепромышленники бурение производили при помощи подрядчиков. Подрядчики были Лисициан, Стрежтельский, Троцаковский ${ }^{3}$ и были подрядчиками ручного бурения. Англичане сами на производстве не работали. Вся производственная работа выполнялась под руководством инженеров, техников, буровых мастеров, механиков, машинистов из русских, армян, лезгин, осетин и других наций.

1911 г., январь. На участке «Победа» из буровой № 3 ударил фонтан легкой нефти с глубины 180 м и загорелся. Были человеческие жертвы 12 человек. Нефть горела, текла по речушке Чекох 4 и речке Пшеха. На участке № 533 немецкой фирмы «Шпис», ударил фонтан тяжелой [нефти] большой силы. За неимением емкости, тары, его мало использовали. Началось бурение на тяжелую нефть на участках № 216, 173, 95.

На участке № 488 и 30 были фонтаны легкой нефти, но промыслы с каждым днем расширялись, добыча нефти все увеличивалась, эксплуатация производилась желонкой тартальным барабаном ${ }^{6}$.

1914 г., 1 августа - была объявлена война с Германией, все военнообязанные, рабочие и служащие 35 лет подлежали мобилизации, допускалась бронь квалифицированным рабочим и служащим. Многие нефтепромышленники, кроме англичан, стали сворачивать 7 работу на промыслах, закрывать свое производство и продавать свое имущество. Работа на промыслах продолжалась, но [в] меньших размерах.

1915 г. - на участке № 457 из буровой № 2 ударил фонтан легкой нефти. 10 марта фонтан загорелся. Были человеческие жертвы - погибло 3 человека.

В 1918 г. много фронтовиков вернулось с фронта, но на работу устроиться не могли, так как англичане не торопились развивать работу на промыслах.

В 1917 г. был создан Комитет Союза горняков ${ }^{8}$. Состав этого комитета: Этцигер - врач, Потапов 9 , Мельников Илья, Стрыгин [Василий] ${ }^{10}$, Буянов, Херселов ${ }^{11}$, Астриев ${ }^{12}$ Артем, Сироткин [Василий] ${ }^{13}$. Культурно-просветительной работы не велось. Правда, была школа,

\footnotetext{
1 Нефтеперекачивающие станции обслуживали нефтепроводы Ширванская-Екатеринодар и Ширванская-Туапсе.

2 Галицийский станок, вероятно это станок канатно-ударного бурения скважин на нефть широко применялся в конце XIX - начале XX вв., особенно в США.

3 Сведениями о подрядчиках мы не располагаем. У П.Н. Соколова упоминается владелец участка № 42a В. А. Тржецяковский (Поколение Октября, 2017: 30; Соколов, 1970: 23).

4 Адыгейское название реки Нефтяной.

5 Желонка - посудина цилиндрической формы, которой вычерпывают жидкость и разрушенную породу, песок, грязь на поверхность из скважины во время бурения, очистки от песчаных пробок, доставляют в скважину цементный раствор, осуществляют пробный отбор жидкости из пласта при освоении скважин.

6 Входит в приспособление для чистки скважин.

7 В тексте: «ликвидировать».

8 То есть местное отделение Всероссийского союза рабочих горняков - в то время профсоюза рабочих горнодобывающих отраслей народного хозяйства.

9 А.Ф. Потапов упоминается как домохозяин в станице Хадыженской в переписи 1920 г.

10 В других источниках: Стригин.

11 Херселов - буровой мастер, член делегации Комитета Союза горняков к В.И. Ленину в 1918 г. по поводу национализации Майкопских нефтяных промыслов. После захвата промыслов белыми исчез. Его судьба неизвестна.

12 В тексте: «Ястриев», ниже: «Асриев».

13 Сироткин Василий - слесарь на промыслах Майнефти, ходок к Ленину в 1918 г. После захвата Майнефти белыми зарублен на Тухинском мосту.
} 
в которой училось 15 учеников ${ }^{1}$. Учительница в школе была Лелехина. Всего рабочих и служащих к началу 1918 г. на промыслах было 520 человек. Промыслы носили название Нефтяные Майкопские промыслы.

Солдаты вернулись с фронта и узнали, что идет спешная подготовка к выборам в Учредительное собрание ${ }^{2}$, назначенное на 12 января 1918 г. Солдаты подсказали Комитету Союза, что вы, товарищи, от жизни ставим вас в известность, что 25 октября 1917 г. произошла вторая революция, партия большевиков и власть Советов рабочих и крестьян под руководством тов[арища] В.И. Ленина. Как видно наш Союз горняков и народ на промыслах об Октябрьской революции мало был проинформирован ${ }^{3}$. Непростительно майкопским политическим организациям как руководящим органам своевременно не информировать рабочих и служащих промыслов о важном событии - Октябрьской революции.

В конце февраля 1918 г. комитет снова получил извещение, что на ${ }^{4}$ Екатеринодар наступает армия [Л.Г.] Корнилова ${ }^{5}$. Комитет Союза послал из Михайловского полка в помощь Красной гвардии кавалеристов и пехоту ${ }^{6}$. Армия Корнилова под Екатеринодаром была разбита7. Сам Корнилов был убит. Остатки армии разбрелись по лесам и горам ${ }^{8}$. Кроме отрядов [Л.Г.] Корнилова к ним примкнули отряды генералов: [А.А.] Геймана, [M.А.] Фостикова 9 . Словом, промысла со всех сторон были окружены бандами ${ }^{10}$. Работать на промыслах стало опасно, рабочие были вооружены винтовками, работая и охраняя промыслы. Около промыслов задерживались нашими партизанами подозрительные личности. Комитет Союза этих лиц отправлял в Майкоп, в Ревком. Однажды был задержан важный преступник [В.Л.] Покровский ${ }^{11}$, его задержал рабочий Шевченко, его тоже отправили в Майкоп, в Ревком. Сопровождали его рабочий Неживой и другие. Что же впоследствии с ним случилось, с [В.Л.] Покровским. Он в Майкопе не был никак ${ }^{12}$ наказан, сохранился в целости ${ }^{13}$. Но 29 августа 1918 г. [В.Л.] Покровский, уже генерал, расправился с жителями Майкопа, по его приказу № 1 было расстреляно 4000 человек, погибших похоронили на кладбище около железнодорожной станции в Майкопе ${ }^{14}$. По приказу [В.Л.] Покровского, [появились в $]^{15}$ станице Хадыженской и Кубанской ${ }^{1}$ кладбища [зарубленных и расстрелянных революционеров $]^{2}$.

\footnotetext{
${ }^{1}$ Речь идет о промысловой школе. В станицах Апшеронской, Нефтяной и Хадыженской в то время работали двухклассные училища.

2 Учредительное собрание - представительный орган в России, избранный в ноябре 1917 г. и созванный в январе 1918 г. для определения государственного устройства России.

3 В тексте: «знаком».

4 В тексте: «В».

5 Автор имеет в виду Добровольческую армию белых.

${ }^{6}$ Михайловский полк был сформирован из рабочих-добровольцев Майкопских нефтяных промыслов.

7 Это явное преувеличение. Добровольческая армия, потеряв главнокомандующего, прекратила штурм Екатеринодара и отступила от города.

8 Автора ввело в заблуждение отступление небольших отрядов добровольцев, отсеченных от основных сил во время прорыва Добровольческой армии из окружения у Великовечного. Под Екатеринодаром Добровольческая армия не была разгромлена. Решение об отступлении принял А.И. Деникин, вступивший в должность командующего после гибели Л.Г. Корнилова.

9 Автор, как и его товарищи, называет генерала уничижительно: «Хвостиков».

10 Автор, подобно многим современникам, сводит воедино действие врагов советской власти. В действительности к Л.Г. Корнилову после прорыва из Великовечного присоединилось войско Кубанской Рады во главе с В.Л. Покровским. Отряды генерала А.А. Геймана пришли на помощь уже А.И. Деникину в 1918 г., а генерал М.А. Фостиков пытался создать в Закубанье Повстанческую армию и помочь десанту С.Г. Улагая в 1920 г.

${ }^{11}$ Виктор Леонидович Покровский - генерал-лейтенант, участник Первой мировой и Гражданской войн. Первопоходник. В 1919 г. командующий Кавказской армией, преемник на этом посту генерала барона П.Н. Врангеля.

12 В тексте: «ничем».

13 Это сообщение легендарно. В действительности В.Л. Покровский в это время воевал вместе с Добровольческой армией. Возможно, это был кто-то из его родственников. Если это так, то в развязывании белого террора в Майкопе у В.Л. Покровского были личные причины.

14 Автор рассказывает о развязанном по приказу В.Л. Покровского белом терроре в Майкопе.

15 В тексте: «есть на».
} 
В марте 1918 г. Комитет Союза горнорабочих был переизбран, в него влились новые члены из фронтовиков: Стрыгин Василий, Литовченко [М.А.]3, Бондаренко [И.К.], Борисов, Провоторов П.Д., Евтихеев, Асриев А., Болтенко Ф.В., Четверик Иван ${ }^{5}$. Новый состав комитета Союза стал называться Совет рабочих, солдатских и крестьянских депутатов.

Рабочие солдаты - фронтовики, кто остался в живых, вернулись на работу, но устроиться на работу не могли, жить нечем, семьи были. Совет рабочих, солдатских и крестьянских депутатов обратился к промышленникам с предложением помочь солдатам, бывшим на войне, оплатить зарплату за время войны. Промышленники неохотно, но согласились оплатить. Итак, солдаты, бывшие рабочие на промыслах, получили зарплату за время войны.

На повестке дня Совета рабочих, солдатских и крестьянских депутатов стоял важный вопрос о национализации промыслов. К этому вопросу нужно [было] подходить очень осторожно. Помощи со стороны [не было]. Этот вопрос обсудить было [не с кем]: с Майкопом и с Екатеринодаром связь была слабая. Майкопские нефтяные промыслы [были] отрезаны [от страны] со всех сторон. Получить какие-либо сведения, что творится вокруг нас, в Москве [было трудно. Обо всем происшедшем] узнавали случайно, от прохожих людей. Некоторые представители общественных организации пытались к нам проехать, но доезжали до Майкопа или Белореченской и возвращались обратно, боялись банд[итов].

В начале мая 1918 г. комитет Союза горняков отправил на лечение больных рабочих в Теберду 615 человек, больных ревматизмом. Через несколько дней узнали, что эти рабочие с промыслов [попали к бандитам], их признали большевиками ${ }^{7}$ 11 человек побили, а 4 человека бежали.

В начале июня 1918 г. Совет рабочих, солдатских и крестьянских депутатов постановил избрать от рабочих и служащих промыслов [делегацию] в количестве трех человек и послать их к товарищу В.И. Ленину в Москву по вопросу национализации Майкопских нефтяных промыслов. Были избраны лучшие товарищи: Клейменов ${ }^{8}$, [Василий] Сироткин, Херселов. Через две недели наша делегаты возвратились от товарища В.И. Ленина. Делегация доложила на общем собрании рабочих и служащих ответ тов[арища В.И.] Ленина нашей делегации, таков:

- Можете национализировать промыслы, если сможете управлять и работать на них, если не сможете, воздержитесь пока.

Промысла понемногу работали, и9 Совету рабочих, солдатских и крестьянских депутатов пришлось послушаться совета В.И. Ленина и вариться в собственном соку.

Из нефтепромышленников на промыслах остались одни англичане: Джеффрис, Байр, Литль, Вискин ${ }^{10}$. Главная контора технического склада была в Апшеронской.

Положение с продуктами питания стало ухудшаться, были магазины и другие торговые лавчонки частников. По праздникам на участке № 14 собирался базар, товары доставлялись из Майкопа. Положение с питанием с каждым днем ухудшалось, частные магазины стали закрываться. Снабжение рабочих продовольствием взял на себя трест «Кубчернефть»11.

\footnotetext{
1 В тексте: «Кубинской».

2 Ныне все хадыженские революционеры перезахоронены в мемориальном комплексе на ул. Коммуны у Майского озера.

3 Литовченко Михаил Андреевич - член Комитета союза.

4 В дальнейшем член подпольного ревкома.

5 Ни один из них в базе нижних чинов - участников Первой мировой войны из станиц Апшеронской, Нефтяной, Самурской, Хадыженской, Ширванской не упоминается. Видимо, они были иногородними или казаками не из закубанских станиц.

6 В тексте ошибочно: «Тиберду». Ныне Теберда - город-курорт в Карачаевском городском округе Карачаево-Черкесской Республики.

7 В тексте: «как большевиков».

8 Клейменов - начальник нефтеперегонной станции нефтепровода Ширванская - Краснодар. Ходок к Ленину в 1918 г. После прихода белых обвинен в саботаже и расстрелян в Апшеронске.

9 В тексте доб.: «так».

10 Возможно, это Я. Вишау.

11 В тексте явная ошибка: Кубано-Черноморский нефтепромысловый трест существовал в 19201924 гг. Видимо, автор имел ввиду Кубано-Черноморский совнархоз.
} 
В течение июня, июля 1918 г. к нам на промыслы приезжали черноморские моряки краснофлотцы с просьбой отпустить им нефть для флота. Конечно, отказа в этом им не было, получили нефть столько, сколько им было нужно.

Числа 17-18 [июня 1918 г.] в совет пришел рабочий Саркисов Александр и сообщил следующее, что он был в горах Тубы ${ }^{1}$, ему сказали армяне, что видели, по направлению к Туапсе $^{2}$ продвигаются грузинские вооруженные отряды. В ст[анице] Нефтяной стояла рота красногвардейцев, мы сообщили об этом командиру роты и попросили его проверить это и иметь связь с Советом рабочих, солдатских и крестьянских депутатов. Мы со своей стороны усилили охрану промыслов.

23 августа 1918 г. вызываем командира роты ст[аницы] Нефтяной, нам отвечают, что рота ушла из ст[аницы] Нефтяной неизвестно куда. Мы звоним в г[ород] Майкоп, вызываем начальника гарнизона поручика Петрова, рассказываем ему о создавшемся положении на промыслах, просим помощи его по охране промыслов. Петров отвечает, что войск у него мало, помочь не может. Совет рабочих, солдатских и крестьянских депутатов собирает общее собрание рабочих, служащих и доложили собранию о создавшемся положении на промыслах. Мы услышали, что через Туапсе по направлению к Белореченской идет большая армия с Тамани под командованием [Е.И.] Ковтюха 3.

26 августа 1918 г. весь состав Совета рабочих, солдатских и крестьянских депутатов и свободных рабочих и служащих от работы, а всего 120 человек, часа в два ночи отправились в ст[аницу] Апшеронскую. В Апшеронской сделали совещание, что делать, постановили дойти до ст[аницы] Пшехской ${ }^{4}$, встретиться с армией таманцев и просить командующего армией о помощи и сохранении промыслов от разрушения. Второй вопрос: возвратить двух членов Совета на промысла для подпольной работы, ликвидировать документы - архивы Совета. Были возвращены товарищи П.Д. Провоторов и И.К. Бондаренко. Совет сказал, что через три дня мы все обратно вернемся на промыслы. Мы еще не вышли из ст[аницы] Апшеронской, как у жителей - мужчин на шапках кубанках появились белые ленты.

Из Апшеронской мы вернулись втроем. Нас сопровождал В.Г. Бондаренко с винтовкой. На третий день после ухода с промыслов наших товарищей явился отряд стражников во главе с приставом Перегудовым. Первое его распоряжение не давать продукты питания тем семьям, у которых рабочие ушли к большевикам, и кто в партизанах, поставили стражу к продовольственному складу. Пришлось, крадучись встретиться с управляющим англичанином Джеффрисом, просить его разрешения отпускать продукты питания семьям рабочих, ушедших с промыслов. Джеффрис твердо сказал: продукты питания отпускать всем без различия, но стража уже узнала, кто из рабочих ушел с промыслов. Положение осложнилось, надо было найти выход. Выход был найден, договорились со складчиками склада, под разными фиктивными фамилиями все семьи стали получать продукты. Складчиками были Лазарев и [Эдмунд Рафаилович] Херцен5.

Начальник стражи Перегудов стал наводить порядки на промыслах. 3.09.1918 г. был арестован Клейменов (он был начальником станции нефтеперекачки промысла Екатеринодара).

Белой армии [А.И.] Деникина потребовалась нефть. Нефть можно было налить в цистерны на станции Хадыжи ${ }^{6}$, но нефть не смогли качать с промыслов; стали пускать моторы и дизеля, не смогли пустить за неимением какой-то детали мотора. Признали Клейменова как

\footnotetext{
${ }^{1}$ Автор, видимо, имел в виду Тубинский перевал, так как Тубинская долина, с находящимися в ней поселками и гора Туба находятся на северных склонах Главного Кавказского хребта. Здесь вряд ли можно было наблюдать продвижение грузинских войск вдоль черноморского побережья.

${ }^{2}$ Грузинские войска двигались в Туапсе из Сочи.

3 В тексте ошибочно «Ковтуна». В действительности, Е.И. Ковтюх командовал колонной Таманской армии, а армию возглавлял И.И. Матвеев.

4 В тексте: «Пшеховской».

5 Возможно, это Герцих Эдмунд Рафаилович (современники, к примеру, Ф.С. Готьван, называли его Герцин). В ноябре 1941 г. он являлся главным инженером Майкопнефтекомбината.

${ }^{6}$ Автор имеет ввиду Хадыженскую станцию Армавир-Туапсинской железной дороги.
} 
вредителя, второе за то, что ездил в Москву к тов[арищу В.И.] Ленину, за национализацию промыслов, за все это Клейменов был расстрелян ${ }^{1}$ в ст[анице] Апшеронской.

17 сентября 1918 г. в ст[анице] Хадыженской расстреляны рабочие - плотник [B.] Новоземцев ${ }^{2}$, рабочий мастер телефонной станции Романов Андрей [Федорович]3.

15 сентября 1918 г. был арестован П.Д. Провоторов, как секретарь Совета рабочих, солдатских и крестьянских депутатов.

20 сентября 1918 г. был судим карательным отрядом генерала [В.Л.] Покровского по приказу №1 в ст[анице] Кубанской, приговорен к расстрелу, но счастливая случайность, спасли добрые люди. В сентябре был арестован рабочий Шевченко, ему тоже грозила смертная казнь, за то, что он в марте 1918 г. поймал генерала [В.Л.] Покровского в лесу, на промыслы привезли его (тоже счастливая случайность - он остался жив).

В сентябре 1918 г. в 4 ст[анице] Нефтяной был арестован и расстрелян рабочий нефтяник Тихон Стрельников.

Все документы и архив Союза и Советов убрали вовремя, в этом помог рабочий, сторож Бондаренко Григорий, не сделав этого, многие рабочие и служащие могли пострадать. Перегудов применял телесные наказания над мужчинами и женщинами. Была выпорота жена рабочего Ивана Ивановича Курдава Пелагея. [П.Д.] Провоторов был взят на особый надзор. Перегудов в свое время собирался отправить его в г[ород] Майкоп. Партизаны, которые еще находились в лесу, неофициально снабжались продуктами со склада.

Наступил 1920 г. Рабочим и служащим все яснее стало известно, где находится Красная армия. Ростов на Дону, Кубанская область, Майкоп - рабочие и служащие этих пунктов с нетерпением ожидали Красную армию.

12 марта 1920 г. в 3 часа дня к нам на промыслы заехала бригада кавалеристов 5 . При встрече красноармейцев рабочие и служащие запели «Интернационал». Пропели только один куплет, дальше слов не знали, пришлось покраснеть перед красноармейцами за нашу политическую отсталость. Отряд кавалеристов переночевал одну ночь и выехал от нас. Через два-три дня на промыслы Хопры ${ }^{6}$ явился [П.Е.] Дыбенко ${ }^{7}$ - командир «дикой» дивизии ${ }^{8}$ с небольшим отрядом. Рабочие и их жены пошли на Хопры, узнали, что «дикая» дивизия находится в ст[анице] Апшеронской, рабочие и их жены с бинтами и перевязочными материалами пошли в Апшеронскую. Оказалось, что «дикая» дивизия преследует отступавшую армию [А.И.] Деникина, донских казаков 9 . Наши рабочие с оружием в руках помогали «дикой» дивизии. Была горячая схватка, но преимущество оказалось на стороне донских казаков. «Дикой» дивизии пришлось отступать к ст[анице] Ширванской. В этом бою наши рабочие потеряли убитыми пять человек: Балмский, Сутягин, Никитин Антон, Томилин Дмитрий. 20 марта 1920 г. погибших товарищей похоронили на вновь отведенном кладбище около водяных резервуаров.

Донские казаки вместо «дикой» дивизии стали преследовать красноармейцев [2-й кавалерийской дивизии] им. [М.Ф.] Блинова ${ }^{10}$ [Первой Конной армии РККА]. Стали обстреливать ст[аницу] Апшеронскую. Служащие нашей главной конторы и технического

\footnotetext{
1 По данным В. И. Уварова зарублен по дороге в Апшеронскую вместе с В. Сироткиным (Уваров, 2010: 22).

2 На памятнике в Хадыженске он записан как В. Иноземцев. В метрических книгах Хадыженской Покровской церкви за 1918-1919 гг. как умерший не упоминается.

3 Романов Андрей (Сосланбек) Федорович (1892-1918) - житель Терской области Владикавказского округа, селения Салугардана, мастер Апшеронской телефонной станции. Его имя написано на памятнике погибшим в Гражданской войне в Хадыженске (Метрическая книга, 1918-1919).

4 В тексте: «на».

5 Майкопские нефтяные промыслы первыми освободили войска Красной армии Черноморья (краснозеленые), которыми командовал И.Б. Швецов.

6 Микрорайон Нефтегорска.

7 В тексте ошибочно: «Дубенко».

8 Весной 1920 г. бывший матрос П.Е. Дыбенко крайне неудачно командовал в РККА 1-й Кавказской «дикой» кавалерийской дивизией в составе 1-й Конной армии, за что был вскоре снят с должности. П.Д. Провоторов подтверждает эту оценку.

9 В действительности это был Кубанский казачий корпус Добровольческой армии А.И. Деникина.

10 Видимо, красноармейцы из 2-й кавалерийской дивизии им. М.Ф. Блинова.
} 
склада стали звонить в Совет рабочих, солдатских и крестьянских депутатов, чтобы их вывезли из ст[аницы] Апшеронской на промыслы. Совет рабочих солдатских и крестьянских депутатов обратился к командиру полка с просьбой разрешить вывести всех наших служащих из Апшеронска, а также рабочих и их семьи. Командир полка успокоил нас, сказал, что стрельба из пушек прекратится. Был разбит один дом Крирошта1.

6 апреля 1920 г. из Майкопа приехала комиссия по национализации Майкопских промыслов. Сиуда Петр Ильич - комиссар ${ }^{2}$, инженер Дешевой ${ }^{3}$ и еще несколько человек (имена их не помню) от Майкопских нефтяных промыслов: Лужбин Алексей Яковлевич - председатель Союза горняков, Провоторов Потап Денисович, Ермаков - техник. Эта комиссия документально оформила соответствующим актом передачу Майкопских промыслов Советскому государству безвозмездно. При передаче Майкопских промыслов Советскому государству никто из англичан не присутствовал. Один из англичан - некто Бейрес женился на русской девушке, ушел в лес, в горы Тубы ${ }^{4}$ и находился там до июня 1920 г. Затем комиссар [П.И.] Сиуда с охраной отправил его в Краснодар, затем были слухи, будто они уехали в Англию.

Совет рабочих, солдатских и крестьянских депутатов был переименован в Союз горнорабочих. После приемки промыслов была проведена полная инвентаризация всего имущества - движимого и недвижимого.

20 апреля 1920 г. под руководством комиссара [П.И.] Сиуды была организована партийная ячейка большевиков. Секретарем был избран Коресцов Дмитрий.

1921 г. в июне месяце на Майкопские нефтяные промысла из Англии приехал Мангомери, рабочие узнали цель приезда в Советский Союз. Оказалось, что Мангомери был в Москве, вел переговоры с тов[арищем В.И.] Лениным о концессии нефтяных промыслов. Рабочие и служащие выказали свое неудовольствие по [этому поводу и призвали] защитить промыслы от сдачи в концессию. [Это] сделал покойный академик Иван Михайлович Губкин. Он доказал В.И. Ленину, [что нет] необходимости сдачи промысла в концессию.

В том же году была организована комсомольская ячейка. Многие из рабочих и служащих, ушедших из промыслов 26 августа 1918 г. с Таманской армией, не вернулись, погибли.

1920 г. в июне на промысла приехал новый управляющий инженер Н.А. Сорокин. Стали подбирать кадры руководителей промыслами: буровым мастером [стал М.Б.] Бадальянц5, по эксплуатации - Г.К. Пелеев и другие специалисты, механики, машинисты. [Стали налаживать и запускать в работу] принятое от англичан имущество и оборудование [в] большинстве старое: станки бурильные галицийские, паровые котлы, паровые машины, насосы, нефтемоторы, газомоторы и др. оборудование. Комиссар [П.И.] Сиуда организовал взвод вооруженных рабочих в обязанности, которых входило 6 охранять промыслы от набегов банд и доставлять на промыслы разные строительные и технические материалы, [а также] продукты питания. Опасной дорога была от станции железной дороги Хадыженская до станицы Хадыженской [и] до Апшеронских промыслов. Все рабочие и служащие, и женщины героически боролись за власть Советов и сохранение промыслов от разрушения.

Ревком Краснодара предписал ревкому ст[аницы] Апшеронской отпустить рабочим и служащим Майкопских нефтяных промыслов много скота на мясо бесплатно. Рабочие и служащие на общем собрании обсудили этот вопрос о подарке скота на мясо, отказались брать его. Базар с участка № 14 переведен на участок № 461, магазин № 5 .

С первых дней взятия промыслов в свои руки рабочие, служащие, инженеры, техники приступили к строительству квартир для рабочих и служащих. Здания производственного значения были построены: кирпичный завод, лесопильный завод, разные склады, мастерские, насосные электростанции и другие необходимые постройки.

\footnotetext{
${ }^{1}$ Кирошта Степан - потомок первопоселенца, охотчего, получившего земельный участок.

2 Сиуда Петр Ильич (1877-1938) - большевик с 1903 г., партийная кличка «Молот». В 1920-х гг. комиссар отряда ЧОН на Кубани. В 1938 г. репрессирован. Погиб в тюрьме.

3 В дальнейшем - глава комиссии по национализации «Майнефти».

4 Автор явно имеет ввиду урочище Тубы в верховьях реки Пшеха.

5 Бадальянц Михаил Борисович - буровой мастер, после Великой Отечественной войны работал мастером в Нефтегорском СПТУ.

6 В тексте: «лежало».
} 
Вследствие неурожая 1920-1921 гг. в нашей Республике была голодовка, наши рабочие и служащие добровольно из последних своих средств согласились отчислить из своего заработка 0,5 \% в помощь голодающим.

О культурно-просветительской работе: оборудован клуб из рабочих казарм на участке 512, стали ставить любительскими силами спектакли, концерты. Руководители клуба были из рабочих, затем в 1922 г. был приглашен красноармеец - культурник т[оварищ] И.И. Да...ев ${ }^{1}$, как специалист, который поставил культурную работу на должную высоту.

Открыли школу на участке 512 в доме управляющего. Учителя были приглашены для школы с университетским и высшим образованием: Ананиев, Федоров, Денисов, Ровицкий. Попечителями над школой были выбраны: Иванов, Протопопов, Комаров, около двух школ семилеток посажены два фруктовых сада. Школы снабжены необходимой мебелью и наглядными пособиями, так как школы находились в ведении предприятия.

1920 г. - построена больница на 25 коек, обслуживающий персонал больницы: Фуфио, Апель², фельдшера: Козич3, Харахаэ, акушерка Попович, зубной врач Самохина.

Все эти учреждения: клуб, школа, больница содержались за счет предприятия промыслов до 1930 г.

1920 г., сентябрь. Комиссар П.И. Сиуда со своим отрядом был в Майкопе и случайно встретил Перегудова, бывшего начальника стражи на промыслах. Рабочий Журавлев убил его из винтовки.

1922 г. Было объединение Союза горнорабочих с Майкопскими нефтяными промыслами. Райком Союза Горняков был назначен в г[ороде] Краснодаре. Членские взносы в Союз рабочих и служащих вносили по 2 \% с рубля.

С 1920 по 1922 г. Рабочие и служащие персонально не вносили 4 в Союз свои членские взносы, а с рабочих удерживала контора по платежной ведомости. Служащие в конторах работали с 8 часов утра до 2-х часов дня [до] 1930 г.

1922 г. райкомом Союза горнорабочих для подготовки кадров нефтяников была открыта в Краснодаре школа десятников, а на промыслах у нас организована школа ФЗУ5 на участке 95.

1923 г. За сохранение промыслов от разрушения ЦИК Народных Комисаров 6 и т[оварищ] Ленин наградили коллектив рабочих и служащих Орденом Трудового Красного Знамени № 37. 1 мая Орден был вручен всему коллективу председателем Совпрофа7 г[орода] Краснодара т[оварищем] Лейнером. Орден принимали: комиссар Петр Ильич Сиуда, председатель Союза Алексей Яковлевич Луконин, секретарь Союза Потап Денисович Провоторов, управляющий промыслами Николай А. Сорокин.

2 мая 1923 г. ударил сильный нефтяной фонтан в буровой № 1.

1923 г. на промыслы в июне были присланы демобилизованные красноармейцы в количестве 60 человек для работы на промыслах.

15 июля 1923 г. был избран поселковый сельсовет ${ }^{8}$. Председателем избран красноармеец Карасон, членами - Устинова, Равилов, Дубовик, Иносин, Шумилов, Шумриков 9 , Кузьмин, Табаков, Белокуров, Лукьянов.

\footnotetext{
1 Фамилия написана неразборчиво.

2 В тексте опечатка: «Апрель». Апель Александр Бернгардович (1889-1949) - видный хирург и организатор здравоохранения в Краснодарском крае и в Республике Адыгея.

3 Козич Иван Трофимович (1889-1967) - окончил фельдшерское училище в Майкопе. Работал фельдшером в хуторах Червяковом и Подольском. В РККА призван не был по возрасту. Фельдшер, главный врач Нефтегорского соединения партизанских отрядов Кубани (1942-1943). Женат. После освобождения Нефтегорского района до пенсии продолжал работать фельдшером.

4 В тексте доб. «каждый».

5 ФЗУ (фабрично-заводское училище) - основной тип начальной профессионально-технической школы в СССР в 1918-1940 гг.

${ }^{6}$ ЦИК СССР - Центральный исполнительный комитет СССР - высший законодательный орган между съездами Советов - смешивается с Советом народных комиссаров - правительством СССР.

7 Совета профсоюзов.

8 Автор имеет ввиду Совет поселка Нефтегорск.

9 Шумриков Михаил Васильевич - старый кадровый рабочий ветеран «Майнефти», перед войной директор конторы изоляции, во время нацистской оккупации района - партизан из 3-го взвода 1-го Нефтегорского партизанского отряда им. Щорса.
} 
1923 г. Началось усиленное строительство квартир для рабочих и служащих, производственных зданий: механическая мастерская, склад для инструментов бурения, склад материалов в городке.

1924 г. - Строительство южного клуба на участке 512 на 150 мест.

1924 г. - строительство большого здания показательного общежития, со столовой рабочим и служащим, впоследствии контора треста.

В конце 1924 г. комиссар [П.И.] Сиуда был отозван в Краснодар, для охраны промыслов прибыл эскадрон кавалеристов. В Южном клубе было установлено кино и радио. 1926 г. в феврале на буровой № 46 ударил фонтан нефти.

1926 г. Майкопские нефтяные промыслы передаются ${ }^{1}$ в подчинение тресту «Грознефть». «Грознефть» прислала два буровых мастера Романенко и Зилаева.

1927 г. - построена дизельная электростанция в Новом городке ${ }^{2}$ (заведующий Пинчук).

1927 г. - построена шоссейная булыжная дорога от ст[аницы] Апшеронской до водяных резервуаров на промыслах.

1927 г. - построена школа семилетка около водяных резервуаров.

1927 г. - шло усиленное строительство квартир рабочим и служащим, торговые помещения, пекарни, магазины и другие служебные помещения от Березок ${ }^{3}$ до участка № 169, сейчас ул. Советская [в поселке Нефтегорск].

1927 г. - 30 июня [на] буровой № 23 ударил сильный фонтан нефти с газом и загорелся, были человеческие жертвы, погибло 18 человек, и были раненые. Управляющий промыслом был инженер Бадин.

1927 г. за неимением квартир рабочим и служащим, управляющий промыслом Нестеров разрешил строить индивидуальные квартиры за свой счет, хутор этот назывался Нестеровским ${ }^{4}$.

1927 г. - построено здание пожарной конной охраны.

1928 г. - на промыслах открыта почта и телеграф.

1928 г. - эксплуатация из скважин нефти перешли от колонки к пожарным насосам.

1928 г. - строительство Нового городка5.

Италии.

1929 г. - появились на промыслах старенькие автобусы «Фиат», «Черный ворон» из

1929 г. - постройка Северного клуба на 300 мест.

1929 г. - прилив жителей на промыслы из разных областей СССР, началось строительство индивидуального частного сектора.

1930 г. - на буровой № 15 ударил сильный фонтан легкой нефти, нефть разлилась на 2 км. 30 июля фонтан от неосторожности загорелся, вокруг него загорелись земля и лес. Ужасная и опасная картина была. Невдалеке от буровой № 15 стояла буровая № 45, приблизительно метров 40о, бурением закончена фонтанная, но закрытая 8 задвижкой, задвижка разорвалась и начал бить фонтан с огнем, фонтан буровой № 45 горел с 30 июля 1930 г. несколько дней, пока не потушили его. Тушить пожар были вызваны пожарные команды из Ростова-на-Дону, Краснодара, Грозного, Баку, пожарные ничего не могли делать. Из Москвы приехал один инженер Рамзин, он вызвал из Донбасса шахтеров, сколько нужно, сделали тоннель к скважине № 4 на глубину 3 метра от поверхности 6 , просверлили отверстие в трубе в скважине, нефть тогда пошла в это отверстие в тоннель, и огонь прекратился, начали качать нефть насосами в земляные амбары и так фонтан работал с 30 июля 1930 г. по апрель 1931 г.

1930 г. из Грозного были привезены два двухскоростных вращательных станка. С ними приехали два буровых мастера Трахманов и Дятлов. Первые скважины пробурены № 14 и 94.

\footnotetext{
${ }^{1}$ В тексте: «вливаются».

2 Микрорайон поселка Нефтегорск.

3 Микрорайон поселка Нефтегорск.

4 Микрорайон поселка Нефтегорск.

5 Микрорайон поселка Нефтегорск.

6 В тексте: «верху».
} 
1930 г. - Майкопские нефтяные промыслы преобразованы в трест «Майнефть», трест «Грознефть» ликвидирован.

1930 г., август Майкопский отдел был реорганизован, промыслы вошли в Апшеронский район, стали называться Апшеронские нефтяные промыслы.

Газета «Вышка» ${ }^{1}$ № 1 вышла 30 августа 1930 г.

1931 г. - появились первые тракторы на промыслах, грузы стали перевозиться не быками, а тракторами.

1931 г. - построена новая больница на $80^{2}$ коек со штатом врачей по всем специальностям, гл[авный] врач Н.Г. Шкитов.

1933 г. - март, приезд на промыслы председателя ЦИК [СССР]3 М.И. Калинина 4.

1931 г. - построен 10 водопровод от водокачки ст[аницы] Ширванской, река Пшеха до промысловых резервуаров.

1932 г. - построена тепловая электростанция в ст[анице] Апшеронской.

1933 г. - построена двухэтажная школа десятилетка.

1934, 1935, 1936 гг. - Нефтегорск был назван городом, первый председатель - Лихачев.

1935-1936 гг. - построено двухэтажное здание детсада.

1936 г. - построено одноэтажное здание - [еще одного] детсада.

1936 г. - построен Дом пионеров.

1940 г. - построено ремесленное училище в ст[анице] Апшеронской, первый директор - Борчук.

Сороковую годовщину Октябрьской социалистической революции [1957] рабочие и служащие, и их семьи праздновали дружно и весело, слушали со вниманием доклад.

Разведка нефти:

1935 г. ст[аница] Тульская5.

1935 г. ст[аница] Келермесская 6.

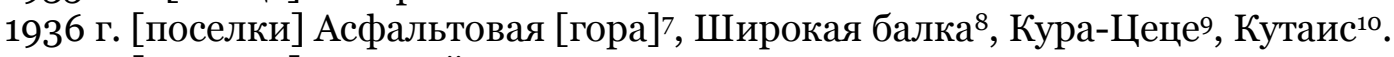

1939 г. [поселок] Горячий Ключ.

\section{Литература}

Винда, 1910 - Винда В.И. Майкопский нефтяной район по исследованиям Нефтяного комитета и личным наблюдениям. Екатеринодар: Печатник, 1910. 30 с.

Винда, 1910-1912 - Винда В.И. Майкопские залежи нефти в связи с нефтепромышленностью Кубанской области. Кудако, Ильский промысел, СуворовскоЧеркесский, Анапа, Тамань. 2-е изд. Ч. 1. Екатеринодар: И.Ф. Бойко, 1910-1912. 404 с.

Винда, 1911а - Винда В.И. Нефтяные и водоносные горизонты Майкопского нефтяного района. Екатеринодар: Печатник, 1911. 53 с.

\footnotetext{
${ }^{1}$ Главный печатный орган Апшеронского, а затем Нефтегорского района до его присоединения к Апшеронскому району.

2 В тексте явная опечатка: «на 8 коек».

3 Центральный исполнительный комитет СССР (ЦИК СССР) - высший орган государственной власти в СССР в 1922-1938 гг.

4 Михаил Иванович Калинин (7 [19].11.1875 - 3.06.1946) - российский революционер, советский государственный и партийный деятель.

5 Ныне - поселок городского типа в Майкопском районе Республики Адыгея, административный центр Майкопского муниципального района и Тульского сельского поселения.

6 Келермесская - станица в Гиагинском муниципальном районе Республики Адыгея. Административный центр Келермесского сельского поселения.

7 Асфальтовая Гора - поселок в Апшеронском районе Краснодарского края. Входит в состав Кабардинского сельского поселения.

8 Широкая балка - хутор станицы Кабардинской в 1917 г. Ныне поселок в муниципальном городском поселении Горячий Ключ Краснодарского края. Входит в состав Кутаисского сельского округа.

9 Кура-Цеце - хутор станицы Линейной в 1917-1925 гг., ныне входит в состав муниципального образования город Горячий Ключ, в Кутаисский сельский округ.

10 Кутаис - поселок в Краснодарском крае, центр Кутаисского сельского округа муниципального образования.
} 
Винда, 1911b - Винда В.И. Обзор положения разведочных буровых работ в Майкопском нефтяном районе по май 1911 г. Екатеринодар: Печатник, 1911. $33 \mathrm{c.}$

Винда, 1916 - Винда В.И. Майкопский нефтяной район и его государственное значение с военной точки зрения. Пг.: С.К. Пентковского, 1916. 21 с.

ГАКК - Государственный архив Краснодарского края.

Галкин, 2003 - Галкин А.И. Вклад И.М. Губкина в изучение Майкопского нефтеносного района: страницы истории / Институт истории естествознания и техники им. С.И. Вавилова РАН: Годичная научная конференция. 2003. М.: Диполь-Т, 2003. С. 469-471.

Готьван, 2012 - Готьван С.Ф. Шумит Гунай. Волгоград: Волгоградский институт управления - филиал РАНХиГС, 2012. 382 с.

Губкин, 1937 - Губкин И.М. Учение о нефти. М.; Л.: ОНТИ, Гл. ред. горно-топл. и геол.-развед. лит., 1937. 459 с.

Дубовицкий, 1966 - Дубовицкий M.M. Иностранный капитал в нефтяной промышленности Кубанской области (60-70 гг. XIX в.-1920 г.): автореф. дисс... канд. ист. наук. Краснодар, 1966. 21 с.

Заборовская и др., 2014 - Заборовская И.О., Тюменцев И.О., Ухина Е.Н. Очерки Ильи Уварова к 10о-летию города Апшеронска (12.04.1863-12.04.1963) - памятник кубанского краеведения // Мир славян Северного Кавказа. Вып. 8. К 6о-летию профессора Э.Г. Вартаньян. Краснодар: Экоинвест, 2014. С. 155-226.

Здравствуй новый социалистический город - Здравствуй новый социалистический город // Вышка. 1935. 30 октября.

Ивин, 2016 - Ивин П.В. Станица Нефтяная 1864-1914. Историческая памятка станицы Нефтяной. Материалы по истории города Хадыженска. Вып. 6. Волгоград: Волгоградский институт управления - филиал РАНХиГС, 2016. 108 с.

Иголкин, 2000 - Иголкин А.А. Нефтяная промышленность России - СССР в 19171928 гг.: дисс... д-ра ист. наук. М., 2000. 505 с.

Косторниченко, 2001 - Косторниченко В.Н. Иностранный капитал в советской нефтяной промышленности 1918-1932 гг.: дисс... д-ра экон. наук. Волгоград, 2001. 361 с.

Метрическая книга Хадыженской - Метрическая книга Хадыженской Покровской церкви за 1918-1919 гг. // Архивный отдел Администрации Апшеронского района. Ф. 348.

Никитенков, 2017 - Никитенков Ф.Т. Станица Кабардинская 1864-1914. Историкогеографический очерк. Материалы по истории города Хадыженска. Вып. 5. Волгоград: Волгоградский институт управления - филиал РАНХиГС, 2017. 88 с.

Поколение Октября, 2017 - Поколение Октября. Материалы по истории города Хадыженска / Сост. И.О. Тюменцев. Волгоград: Волгоградский институт управления филиал РАНХиГС, 2017. 136 с.

Пономарев, Штейнер, 1958 - Пономарев К.П., Штейнер С.И. Очерки истории нефтяной промышленности Кубани. М.: Гостоптехиздат, 1958. 97 с.

Сильванюк, 2011 - Сильванюк Н.И. Майкопское нефтяное чудо // Вестник Адыгейского государственного университета. Серия 1: Регионоведение: философия, история, социология, юриспруденция, политология, культурология. 2011. Вып. 4. С. 79-83.

Сильванюк, 2012 - Сильванюк Н.И. Нефтяная промышленность Кубани в 1920-е годы

// Вестник Адыгейского государственного университета. Серия 1: Регионоведение: философия, история, социология, юриспруденция, политология, культурология. 2012. Вып. 4. С. 78-84.

Сирота, 2017 - Сuрота Г.С. Сочинения по истории станицы Хадыженской. Материалы по истории города Хадыженска. Вып. 4. Волгоград: Волгоградский институт управления филиал РАНХиГС, 2017. $72 \mathrm{c.}$

Соколов, 1970 - Соколов Н.П. Справка об истории, революционных заслугах и вкладе в дело социалистического строительства нашей страны за годы пятилеток нефтяников НПУ «Хадыженнефть». 1970 // Архивный отдел Администрации Апшеронского района. Ф. 347. Оп. 5. Д. 4. 1970 г. Л. 22-27.

Уваров, 2010 - Уваров В.И. Воспоминания о Нефтегорске. Рукопись, 2010. 41 с.

Юшкин, 1910 - Юшкин Е.М. Майкопский нефтяной фонтан // Кубанский сборник. Екатеринодар, 1910. Т. 15. С. $380-383$. 


\section{References}

Dubovitskii, 1966 - Dubovitskii, M.M. (1966) Inostrannyi kapital v neftianoi promyshlennosti Kubanskoi oblasti (60-70 gg. XIX v. - 1920 g.) [Foreign capital in the oil industry of the Kuban region (60-70 years of the XIX century - 1920)]. PhD Thesis (History). Krasnodar, 21 p. [in Russian]

GAKK - Gosudarstvennyi arkhiv Krasnodarskogo kraia [State Archiv of the Krasnodar Kray].

Galkin, 2003 - Galkin, A.I. (2003) Vklad I. M. Gubkina v izuchenie Maikopskogo neftenosnogo raiona: stranitsy istorii [The contribution of I.M. Gubkin in the study of the Maikop oil-bearing region: pages of history]. Institut istorii estestvoznaniia i tekhniki im. S.I. Vavilova RAN: Godichnaia nauchnaia konferentsiia. Moscow: Dipol'-T, pp. 469-471. [in Russian]

Got'van, 2012 - Got'van, S.F. (2012). Shumit Gunai [The Gunay is noisy]. Volgograd: Volgograd Institute of Management - Branch of RANEPA, 382 p. [in Russian]

Gubkin, 1937 - Gubkin, I.M. (1937). Uchenie o nefti [The doctrine of oil]. Moscow Leningrad: ONTI, Main editorial office of mining and fuel and geological prospecting literature, 459 p. [in Russian]

Igolkin, 2000 - Igolkin, A.A. (2000). Neftianaia promyshlennost' Rossii - SSSR v 19171928 gg.: [The oil industry of Russia - the USSR in 1917-1928]: Dr diss. (History). Moscow, 505 p. [in Russian]

Iushkin, 1910 - Iushkin, E.M. (1910). Maikopskii neftianoi fontan [Maikop oil gusher]. Kubanskii sbornik. Ekaterinodar, Vol. 15. Pp. 380-383. [in Russian]

Ivin, 2016 - Ivin, P.V. (2016) Stanitsa Neftianaia 1864-1914 Istoricheskaia pamiatka stanitsy Neftianoi. Materialy po istorii goroda Khadyzhenska [The Neftianaia village 1864-1914. Historical memo of the Neftianaia village. Materials on the history of the Khadyzhensk city]. Is. 6. Volgograd: Volgograd Institute of Management - Branch of RANEPA, 108 p. [in Russian]

Kostornichenko, 2001 - Kostornichenko, V.N. (2001). Inostrannyi kapital v sovetskoi neftianoi promyshlennosti 1918-1932 gg. [The Foreign capital in the Soviet oil industry 19181932]: Dr diss. (Economic science). Volgograd, 361 p. [in Russian]

Metricheskaia kniga Khadyzhenskoi - Metricheskaia kniga Khadyzhenskoi Pokrovskoi tserkvi za 1918-1919 gg. [Metric book of Khadyzhenskaya Pokrovskaya church for 1918-1919]. Arkhivnyi otdel Administratsii Apsheronskogo raiona [Archive department of the Administration of the Absheron region]. F. 348. [in Russian]

Nikitenkov, 2017 - Nikitenkov, F.T. (2017). Stanitsa Kabardinskaia 1864-1914. Istorikogeograficheskii ocherk. Materialy po istorii goroda Khadyzhenska [The Kabardinskaya village 1864-1914. Historical and geographical sketch. Materials on the history of the Khadyzhensk city]. Is. 5. Volgograd: Volgograd Institute of Management - Branch of RANEPA, 88 p. [in Russian]

Pokolenie Oktiabria, 2017 - Pokolenie Oktiabria. Materialy po istorii goroda Khadyzhenska (2017) [Generation October. Materials on the history of the Khadyzhensk city. Comp. Tyumentsev I.O. Volgograd: Volgograd Institute of Management - Branch of RANEPA, 136 p. [in Russian]

Ponomarev, Shteiner, 1958 - Ponomarev, K.P., Shteiner, S.I. (1958). Ocherki istorii neftianoi promyshlennosti Kubani [Issays on the history of the oil industry of the Kuban]. Moscow: Gostoptekhizdat, 97 p. [in Russian]

Sil'vaniuk, 2011 - Sil'vaniuk, N.I. (2011). Maikopskoe neftianoe chudo [Maikop oil miracle]. Vestnik Adygeiskogo gosudarstvennogo universiteta. Seriia 1: Regionovedenie: filosofiia, istoriia, sotsiologiia, iurisprudentsiia, politologiia, kul'turologïa. 4: 79-83. [in Russian]

Sil'vaniuk, 2012 - Sil'vaniuk, N.I. (2012). Neftianaia promyshlennost' Kubani v 1920-e gody [Oil industry of the Kuban in the 1920s]. Vestnik Adygeiskogo gosudarstvennogo universiteta. Seriia 1: Regionovedenie: filosofiia, istoriia, sotsiologiia, iurisprudentsiia, politologiia, kul'turologiia. 4: 78-84. [in Russian]

Sirota, 2017 - Sirota, G.S. (2017). Sochineniia po istorii stanitsy Khadyzhenskoi. Materialy po istorii goroda Khadyzhenska [Essays on the history of the Khadyzhenskaya village. Materials on the history of the Khadyzhensk city]. Is. 4. Volgograd: Volgograd Institute of Management Branch of RANEPA, 72 p. [in Russian]

Sokolov, 1970 - Sokolov, N.P. (1970). Spravka ob istorii, revoliutsionnykh zaslugakh i vklade $\mathrm{v}$ delo sotsialisticheskogo stroitel'stva nashei strany za gody piatiletok neftianikov NPU „Khadyzhenneft"” [Information about the history, revolutionary merits and contribution to the socialist construction of our country during the five-year plans of oil workers of the NPU 
„Khadyzhenneft”]. Arkhivnyi otdel Administratsii Apsheronskogo raiona. F. 347. Op. 5. D. 4. L. 2227. [in Russian]

Uvarov, 2010 - Uvarov, V.I. (2010). Vospominaniia o Neftegorske [Memories about Neftegorsk]. Manuscript, 41 p. [in Russian]

Vinda, 1910 - Vinda, V.I. (1910). Maikopskii neftianoi raion po issledovaniiam Neftianogo komiteta i lichnym nabliudeniiam [Maikop oil region according to the research of the Oil Committee and personal observations]. Ekaterinodar: Pechatnik, 30 p. [in Russian]

Vinda, 1910-1912 - Vinda, V.I. (1910-1912). Maikopskie zalezhi nefti v sviazi s neftepromyshlennost'iu Kubanskoi oblasti. Kudako, Il'skii promysel, Suvorovsko-Cherkesskii, Anapa, Taman'. 2nd ed. Ekaterinodar: I.F. Boiko, 400 p. [in Russian]

Vinda, 1911a - Vinda, V.I. (1911). Neftianye i vodonosnye gorizonty Maikopskogo neftianogo raiona [Oil and aquifers of the Maykop oil region]. Ekaterinodar: Pechatnik, 53 p. [in Russian]

Vinda, 1911b - Vinda, V.I. (1911). Obzor polozheniia razvedochnykh burovykh rabot v Maikopskom neftianom raione po mai $1911 \mathrm{~g}$. [Review of the state of exploration drilling in the Maykop oil region up to May 1911]. Ekaterinodar: Pechatnik, 33 p. [in Russian]

Vinda, 1916 - Vinda, V.I. (1916). Maikopskii neftianoi raion i ego gosudarstvennoe znachenie $\mathrm{s}$ voennoi tochki zreniia [Maikop oil region and its state significance from a military point of view]. Pg.: S.K. Pentkovskogo, 21 p. [in Russian]

Zaborovskaia i dr., 2014 - Zaborovskaia, I.O., Tiumentsev, I.O., Ukhina, E.N. (2014) Ocherki Il'i Uvarova k 100-letiiu goroda Apsheronska (12.04.1863-12.04.1963) - pamiatnik kubanskogo kraevedeniia [Essays by Ilya Uvarov for the 100th anniversary of the city of Apsheronsk (04.12.1863-04.12.1963) - a monument of Kuban local history]. Mir slavian Severnogo Kavkaza [World of the Slavs of the North Caucasus]. Is. 8. K 6o-letiiu professora E.G. Vartan'ian. Krasnodar, Ekoinvest, pp. 155-226. [in Russian]

Zdravstvui novyi sotsialisticheskii gorod - Zdravstvui novyi sotsialisticheskii gorod (1935) [Hello new socialist city]. Vyshka. October, 30. [in Russian]

\section{Майкопские нефтяные промыслы в годы Великой Октябрьской революции и Гражданской войны 1918-1922 гг. (по воспоминаниям Потапа Денисовича Провоторова)}

\section{Подготовка к публикации, вступительная статья и комментарии}

Игорь Олегович Тюменцев ${ }^{\text {a , * }}$

а Волгоградский институт управления Российской академии народного хозяйства и государственной службы при Президенте Российской Федерации, Российская Федерация

Аннотация. Впервые вводятся в научный оборот воспоминания одного из старейших работников Майкопских нефтяных промыслов, секретаря Союза горняков Потапа Денисовича Провоторова о начале нефтяных разработок в Майкопском отделе Кубанского казачьего войска, о событиях Революции и Гражданской войны 1917-1922 гг. и начале социалистического строительства. Автор, хотя и принадлежал к поколению революционеров и во время описываемых событий являлся членом РКП(б), по неизвестным причинам, в 30-50-е гг. XX в. выпал из местной номенклатуры и закончил свою трудовую деятельность простым рабочим. Свои восспоминания он написал для юбилейного сборника «Поколение Октября», в который они, видимо по политическим причинам, включены не были. Хотя это единственные известные нам воспоминания о революционных событиях на «Майнефти».

Ключевые слова: начало нефтяных разработок на Северном Кавказе, Майкопские промыслы и революция, Красные, белые, зеленые, Установление советской власти.

\footnotetext{
* Корреспондирующий автор

Адрес электронной почты: tijumencev@mail.ru (И.О. Тюменцев)
} 